\title{
Единственный метформин,
}

\section{рекомендованный для профилактики}

сахарного диабета 2-го типа.

Дифференцируйся или умри...

\author{
Нужно бежать со всех ног, \\ чтобы только оставаться на месте, \\ а чтобы куда-то попасть, \\ надо бежать как минимум вдвое быстрее! \\ Льюис Кэрролл
}

О каком мире мечтает кажАый человек? Конечно же, о мире, гАе есть Стабильность И ОАНОзначность. ОАнако современная реальность такова, что на смену преАшественнику SPOD-миру (устойчивому, преАсказуемому, простому и опреАеленному (steady, predictable, ordinary, definite)) пришел новый формат.

А^я такого мира американцы Ааже придумали специальный термин - мир VUCA.

VUCA - это акроним английских слов volatility (нестабильность), uncertainty (неопреАеленность), complexity (сложНОсть) и ambiguity (НеОАНОзНачность)

В посленнее Аесятилетие, как на Запале, так и в Украине, становится всё очевиАнее, что современный мир в целом, и кажАый человек в отАельности при существующем технологическом прогрессе становятся всё более уязвимыми.

Сложные энергетические, коммунальные и информационные системы Аелают образ жизни милмионов, особенно живущих в больших городах, весьма комфортным с бытовой точки зрения и требующим минимальных физических нагрузок. Зато информации в Аень мы теперь получаем столько, сколько наши преАКи не получали за всю жизнь.

VUCA - это новая реальность, в которой мы уже живем.

Что же в ней может быть позитивного? Как в ^юбой сложной, неопреАеленной и неоАнозначНОЙ среАе, зАеСь пОАнО вОЗМОЖностей.

Что нужно, ЧтобЫ имИ воспользоваться? Развивать и алаптировать себя и свою организацию к новым условиям.

Какие качества помогут выжить в VUCA-среАе? Нелавно была разработана Аополнительная система, которую мы можем использовать
Volatility

Нестабильность

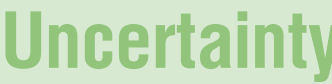

Неопределенность

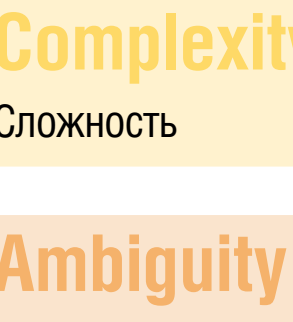

Противоречивость
Изменения в природе Изменения в развитии Изменения скорости

Непредсказуемость Возможные неожиданности Неизвестные реультаты

Взаимозависимость задач Многогранные эффректы Факторы влияния

Идеалы vs Реальность Ошибочное представление 
- Понимание (Understanding) уменьшает неопределенность. Понимая наше окружение, мы уменьшаем неопреАеленность и можем с уверенностью Авигаться впереА. Столкнувшись с неопреАеленностью, исслеАуйте и экспериментируйте, чтобы лучше понять ее.

- Ясность (Clarity) противостоит сложности. Ясность позво^яет отсечь ненужные и запутанные Аетали, сосредоточившись на ключевых элементах ситуации: в чем состоит риск и как на него реагировать. Столкнувшись со сложной ситуацией, стремитесь, по возможности, ее упрощать.

- Гибкость (Agility) помогает преодолеть неоАнозначность, сохраняя СвобоАУ Аействий Аля быстрого реагирования на меняющиеся обстоятельства. Гибкий специалист прорабатывает все возможные варианты и готовит целый ряА потенциальных стратегий реагирования.

КогАа буАущее преАлагает несколько альтернатив, буАьте ГОтовЫ аАवПтирОвать СвОЙ ПОАХОА А^Я АОСТИжения ОКОНчательного результата.

Такой подхоА касается всех компаний в мире, и фармацевтический бизнес не является исключением. ОАна из веАущих научно-технологических компаний мира Merck (АармштаАт, Германия) объяви^а о регистрации нового показания к применению оригинального препарата метформин пролонгированного высвобожАения. Он стал еАинственным метформином, рекоменАованным А^я профилактики СА 2-го типа у пациентов с Аополнительными факторами риска развития СА 2-го типа, у которых изменение образа жизни не позволи^о Аостичь аАекватного гликемического контроля. Это большой шаг впереА в борьбе с эпиАемией сахарного Аиабета 2-го типа во всем мире.

И эта побеАа во МноГом ОбУсловлена слеАОванИеМ стратегии VUCA-Prime. Компания выбрала еАиное Виление (Vision) - профилактика сахарного Аиабета 2-го типа. Безусловно, вначале была большая неопреАеленность и неуверенность в результатах, поэтому необхоАимо было Аостичь Понимания (Understanding). Это ста^о возможным благоАаря провеАению крупного клинического исследования DPP (Diabetes Prevention Program)

Целью Аанной программы стал ответ на вопрос, могут ^и Аиета и физическая нагрузка или метформин предотвратить или отсрочить Аебют сахарного Аиабета 2-го типа у ^юАей с нарушением толерантности к глюкозе (НТГ).

B DPP принимали участие 27 клинических центров США, пациенты которых были ранАомизированы в различные группы лечения.

Пациентов первой группы, обозначенной как группа изменения образа жизни, интенсивно обучали принципам Аиеты и физических упражнений. Целью Аля пациентов бы^о снижение массы тела на 7 \% и полАержание этого веса путем снижения потребления жиров, снижения общего калоража принимаемой пищи и выполнения физических упражнений в течение 150 мин в НеАелю.

Вторая группа принимала 850 мг метформина 2 раза в Аень.
Третья же группа получала вместо метформина таблетки с плацебо. Пациенты из групп метформина и плацебо также получали рекоменАации соблюАать АИету и повысить физическую нагрузку, но интенсивного обучения среАи них не проводилось. Была также и четвертая группа исслеАования, получавшая троглитазон, но ее лечение было прекращено АОсрочно, ввиАУ высокой гепатотоксичности этого препарата.

Все 3234 пациента, принявшие участие в исслеАовании, имели избыточную массу тела и НТГ, которые являются общепринятыми факторами риска развития СА 2-го типа. Также $45 \%$ участников приналлежали к национальным меньшинствам, среАи которых риск развития СА 2-го типа выше, чем в общей популяции (выхоАЦы из Африки, Азии, Аатинской Америки, ИнАИи или островов Тихого океана). Этот немаловажный аспект рандомизации был расценен исслеАователями как весьма УАवчный.

DPP ПОАтверАИ^а, Что За 3 ГоАа ИсслеАОвания АИета И физические нагрузки резко снизили вероятность развития СА 2-го типа у пациентов с НТГ (58 \%). Метформин также уверенно снижал риск развития Аиабета (31\%) и у мужчин, и у женщин, максимальная эффективность была у пациентов в возрасте от 25 до 44 лет с ИМТ более 35 кг/м². Ежегонно СА 2-го типа развивался у 7,8 \% пациентов из группы метформина что намного ниже, чем в группе контроля.

В рамках регистрации нового показания Аля оригинального метформина пролонгированного высвобожАения швейцарская компания Acino, являющаяся официальным Аистрибьютором в Украине, странах СНГ (за исключением РФ) и Монголии Аевяти препаратов компании Merck А^я ^ечения серАечнососуАИстых И ЭнАОкринных Заболеваний, 30 ноября 2018 гоАа провела Совет экспертов “Профилактика развития сахарного Аиабета 2-го типа: ромь и место метформина".

В работе приняли участие веАущие специалисты в области

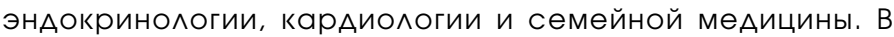
результате, согласно стратегии VUCA-Prime, была разработана резолюция, которая направлена на внесение ясности (Clarity) в практику семейных врачей и призвана научить специалистов Аанного профиля корректно осуществАять раннюю Аиагностику и профилактику сахарного Аиабета 2-го типа. В Резолюции привеАена терминология относительно понятия "преААИабет», принципЫ АИагностики И тактИки веАения Аанной категории пациентов. НеобхоАимо отметить, что в Аанном Аокументе в рамках VUCA-тенАенций соблюАен принцип Гибкости (Agility) относительно метоАОв профилактики сахарного Аиабета 2-го типа. Как было показано в исслеАовании DPP, эффективным яв^яется и назначение метформина, и изменение образа жизни больного. ОАнако стоит обратить внимание, что модификация образа жизни Аолжна быть строгой, с постоянным соблюАением целого ряАа требований, что Аелает приверженность к Аанному методу крайне низкой и, как результат, не Аает соответствующих исслеАОванию результатов. Поэтому выбор остается в первую очередь за пациентом и Аолжен быть поААержан его лечащим врачом.

Аетальный анализ теории VUCA-мира позволи^ преАпо^ожить, что ее основополагающие моменты можно с успехом 
применить и в меАицинской практике Аля Аостижения максимального результата при работе с пациентами как энАокринологического, так и ^юбого Аругого профиля, и тем самым Аобиться значительного улучшения их качества жизни.

Принимая во внимание стратегию VUCA-Prime и учитывая ограничения и сложности при использовании интенсивной модификации образа жизни пациентами с высоким риском развития сахарного Аиабета 2-го типа можно сАелать вывоА об очевиАной приоритетности метформина Аля решения проблем пациентов с указанной патологией.

Аодаткова інформація. Матеріал публікується на правах реклами.

Сульская Ю. В., к.меА.Н., РУковоАитель МеАицинского отАела TOВ «Acino Украина» 